cortex were discussed relating to the compact, clear and the glomerulosa cell types.

\title{
References
}

1) Carr, I. : J. Path. Bact., $81: 101,1960 . \quad$ 2) Lever, J. D. : Amer. J. Anat., $97: 409,1955$.

3) Maeda, R., Takada, R. and Yamagata, I. : Proc. Jap. Histochem. Ass., $2: 211,1961$.

Okamoto, K., Shimamoto, H. and Sonoda, H. : Jap. J. Constitutional Med., $13: 113,1944$.

5) Pearse, A. G. E. : Histochemistry, theoretical and applied. Churchill, London, 1960.6 6)

Symington, T. : Brit. Med. Bull., $18: 117,1962.7$ 7) Symington, T.: The human adrenal cortex, pp. 3-20, Livingstone, Edinburgh, 1962.

\section{Histochemical Demonstration of Hydrolytic and Oxidative Enzymes in Osteoclasts under Normal and Pathological Conditions}

\author{
Kazuaki Takada, Hiroyuki Toda, Kinji Yoshrkawa and \\ Masahiko Mori
}

Department of Oral Surgery, Osaka University Dental School, Osaka.

(Director : Prof. Kensaku Kawakatsu)

\section{Introduction}

The osteoclast is generally thought to have an integral relationship with bone resorption. Although studies on osteoclasts have been made from histological, physiological and biochemical standpoints, there seem a few histochemical report made about biological significances of osteoclasts. The materials of these studies are almost non-decalcified specimens. Recently, according the advancement of histochemical techniques for the demonstration of enzymes and improvement of decalcifying method for hard tissue, it becomes possible to demonstrate the enzymatic localization on osteoclasts in matured calcifying structures. In the present study, the localization of hydrolytic and oxidative enzymes on osteoclasts were carried out in decalcified specimens.

\section{Material and Method}

The knee josnts of adult guinea pig and 7 day old rat, the regenerating bone tissue from callus, 2 weeks after fracture and from 2 weeks after extraction of molar, and osteoclastoma of human tumor, were used in the present study. They were decalcified with neutral EDTA solution and rinsed with 
running tap water and cut at $15-20 \mu$ in a $-20^{\circ} \mathrm{C}$ cryostat with a sliding microtome.

For the histochemical demonstration of hydrolytic enzymes (alkaline and acid phosphatase, glucuronidase, esterase and aminopeptidase) the azo dye coupling methods were used. For the oxidative enzymes (malic, lactic, glutamic, $\alpha$-glycerophosphate, $\beta$-hydroxybutyric, isocitric, glucose 6 -phosphate and succinc dehydrogenases) Nitro-BT were applied for electron accepter.

\section{Result and Conclusion}

Results of enzymatic stainabilities for hydrolytic and oxidative enzymes were summarized as follows.

\begin{tabular}{|c|c|c|c|c|c|}
\hline \multirow[b]{2}{*}{ Alkaline phosphatase } & \multicolumn{2}{|c|}{$\begin{array}{c}\text { Epiphysis } \\
\text { Knee Joint } \\
\text { Osteoclasts Osteoblasts }\end{array}$} & \multicolumn{2}{|c|}{$\begin{array}{c}\text { Regenerating Bone } \\
\text { Fracture Callus } \\
\text { Extraction Wound } \\
\text { Osteoclasts Osteoblasts }\end{array}$} & \multirow{2}{*}{$\begin{array}{c}\begin{array}{c}\text { Tumor } \\
\text { Osteoclastoma } \\
\text { Giant Cell }\end{array} \\
+\end{array}$} \\
\hline & $+\sim \pm$ & $H \sim+$ & $+\sim \pm$ & $H \sim+$ & \\
\hline Acid phosphatase & $H \sim+$ & $+\sim \pm$ & H & + & $H$ \\
\hline Esterase & - & - & - & - & - \\
\hline$\beta$-Glucuronidase & H & + & $H$ & + & H \\
\hline Aminopeptidase & (guinea pig & $\left(1{ }^{-}+\right)$ & + & + & \pm \\
\hline Succinic dehydrogenase & H & H & H & + & m \\
\hline Lactic dehydrogenase & m & H & H & $H$ & m \\
\hline Malic dehydrogenase & H & $H$ & H & $H$ & m \\
\hline Glutamic dehydrogenase & $H$ & + & $H$ & + & $H$ \\
\hline $\begin{array}{l}\alpha \text {-Glycerophosphate } \\
\text { dehydrogenase }\end{array}$ & + & \pm & + & \pm & + \\
\hline $\begin{array}{l}\beta \text {-Hydroxybutyric } \\
\text { dehydrogenase }\end{array}$ & + & \pm & + & \pm & + \\
\hline $\begin{array}{l}\text { Glucose-6-phosphate } \\
\text { dehydrogenase }\end{array}$ & + & + & + & + & + \\
\hline Isocitric dehydrogenase & + & + & + & + & + \\
\hline
\end{tabular}

Osteoclast presented in the normal epiphysial bone and in regenerating bone such as callus after fracture and extraction showed a same pattern of histochemical stainabilities. Giant cells in the human osteoclastoma also showed alike histochemical appearance to osteoclasts in bone tissue.

In general, succinic, dehydrogenase activity is the highest in osteoclasts and giant cell. In osteoclasts, acid phosphatase activity is stronger than alkaline phosphatase while on the contrast, alkaline phosphatase activity is stronger than acid phosphatase in osteoblasts. Aminopeptidase activity was not so markedly demonstrated in osteoclasts. NAD dependent dehydrogenase activities also showed a more positive reaction in osteoclasts than that of osteoprogenital cells. NADP dependent dehydrogenase activities in both osteoclasts and osteoblasts were almost the same or a little weaker in osteoclast than in osteoblasts. It 
was reported that local $\mathrm{pH}$ around the osteoclasts showed a lower degree in the case of cell culture. From these findings it could be thought that in the mechanism of bone resorption by osteoclasts, the demineralizing action occupys more important part than the proteolytic action. Localization of succinic dehydrogenase activity coincided with the mitochondrial distribution, that is, functional side, which is adjacent to bone and rich in mitochondria, show a high enzymatic activity. These patterns indicated histochemically that there is the differences in mechanism and function of these cells.

\title{
References
}

1) Balogh, K. : Lab. Invest. 10, 839-845 (1961). $\quad$ 2) Balogh, K. : J. Histochem. Cytochem. 10, 232-233 (1962). 3) Burstone, M.S. : J. Histochem. Cytochem. 7, 39-41 (1959). 4) Freiman, D.G. : Proc. Soc. Exp. Biol. Med. 84, 338-341 (1953). 5) Fullmer, H.M. : J. Histochem. Cytochem. 12, 210-214 (1964). 6) Fullmer, H.M. and Link, C.C. : Stain Tech. 39, 387-396 (1964). 7) Hancox, N.M. and Boothroyd, B. : J. Biophys. Biochem. Cytol. 11, 651-661 (1961). 8) Handelman, C.S., Morse, A. and Irving, J. T. : Am. J. Anat. 115, 363376 (1964). 9) Mori, M., Takada, K. and Osanai, K. : Histochemie. 2, 427-434 (1962). 10) Mori, M., Ito, M. and Fukui, S. : Histochemie. (in press). 11) Mose, A. and Greep, R.O.: Arch. Oral Biol. 2, 38-45 (1960). 12) Schajowic, F. and Cabrini, R.L. : Science 131, 10431044 (1960). 13) Takada, K., Tani, T. and Mori, M. : Rinsho Byori (Japan) 8, 237-240 (1960). 14) Takada, K. and Osanai, K. : Arch. histol. jap. 22, 265-271 (1962). 15) Takada, K. : Acta. Histochem. (in press) (1965).

\section{The Enzyme Histochemical Study on the Trigeminal}

\section{Ganglions of Cows, Dogs, Cats and Rabbits}

\author{
Hideo MatsuUra, Masahiko Mori and Kensaku Kawakatsu \\ Department of Oral Surgery, Osaka University Dental School, Osaka
}

Recently histochemical studies on the ganglions of mammals have been made, centering around the hydrolytic enzymes. In the present study, it is attempted to clarify the distribution patterns for oxidative enzymes and hydrolytic enzymes in the trigeminal ganglions of cows, dogs, cats and rabbits.

\section{Materials and Methods}

The trigeminal ganglions were removed immediately after the animals were clashed to death. Fresh specimens were frozen and cut, 12-18 microns thick in a cryostat at $-20^{\circ} \mathrm{C}$. Oxidative enzymes (succinate, lactate, malate, glutamate, alpha-glycerophosphate, beta-hydroxybutyrate, glucose-6-phosphate, isocitrate, dehydrogenases and monoamine oxidase) and aldolase were demon- 